\title{
How and why do French medical students choose the specialty of infectious and tropical diseases? A national cross-sectional study
}

Nathan Peiffer-Smadja ${ }^{1,2,3^{*}}$ (D) François-Daniel Ardellier ${ }^{4}$, Pauline Thill', Anne-Lise Beaumont ${ }^{1}$, Gaud Catho ${ }^{1}$, Lindsay Osei ${ }^{1}$, Vincent Dubée ${ }^{1}$, Alexandre Bleibtreu ${ }^{1}$, Adrien Lemaignen ${ }^{1}$ and Michaël Thy ${ }^{1,5}$

\begin{abstract}
Background: Infectious and tropical diseases (ID) physicians are needed now more than ever to tackle existing and emerging global threats. However, in many countries, ID is not recognized as a qualifying specialty. The creation of ID residency in 2017 in France offers the opportunity to know how and why the specialty is chosen by medical students.

Methods: We first analyzed the choice of specialty of all French medical students in 2017 and 2018 according to their rank at the national exam that ends medical studies. A web questionnaire was then sent in January 2019 to all ID residents in France $(n=100)$ to assess the factors influencing their choice of specialty and their career plan.

Results: We analyzed the choice of 17,087 medical students. ID was the first-chosen specialty with a median national rank of 526/8539, followed by plastic surgery and ophthalmology. The questionnaire was completed by $90 \%$ of the French ID residents $(n=100)$. The most encouraging factors to choose ID were the multisystem approach of the specialty, the importance of diagnostic medicine and having done an internship in ID during medical school. The potential deterrents were the work-life balance, the workload and the salary.

Conclusions: The recent recognition of ID as a qualifying specialty in France can be considered a success insofar as the specialty is the most popular among all medical and surgical specialties. Individuals who choose ID are attracted by the intellectual stimulation of the specialty but express concerns about the working conditions and salaries.
\end{abstract}

Keywords: Career choice, Infectious diseases education, Perception of infectious diseases, Residency

\footnotetext{
* Correspondence: nathan.psmadja@gmail.com

'RéJIF, Young French Infectious Diseases Physicians' Network - Réseau des Jeunes Infectiologues Français, Paris, France

${ }^{2}$ Infectious Diseases Department, Bichat-Claude Bernard Hospital, Assistance-Publique Hôpitaux de Paris, Paris, France

Full list of author information is available at the end of the article
}

(c) The Author(s). 2020 Open Access This article is licensed under a Creative Commons Attribution 4.0 International License, which permits use, sharing, adaptation, distribution and reproduction in any medium or format, as long as you give appropriate credit to the original author(s) and the source, provide a link to the Creative Commons licence, and indicate if changes were made. The images or other third party material in this article are included in the article's Creative Commons licence, unless indicated otherwise in a credit line to the material. If material is not included in the article's Creative Commons licence and your intended use is not permitted by statutory regulation or exceeds the permitted use, you will need to obtain permission directly from the copyright holder. To view a copy of this licence, visit http://creativecommons.org/licenses/by/4.0/ The Creative Commons Public Domain Dedication waiver (http://creativecommons.org/publicdomain/zero/1.0/) applies to the data made available in this article, unless otherwise stated in a credit line to the data. 


\section{Background}

In 2019, the World Health Organization published a list of 10 threats to global health among which 6 are related to infectious and tropical diseases (ID): the threat of a global influenza pandemic, antimicrobial resistance, Ebola and other high-threat pathogens, vaccine hesitancy, dengue, and HIV [1]. ID specialists' consultations have been shown to decrease mortality rates and healthcare costs and antimicrobial stewardship programs have shown to reduce the number of infections with resistant bacteria [2-5]. In the context of the COVID-19, ID physicians are needed now more than ever to tackle this pandemic as well as the future ones and improve outcomes for patients [6].

However, in many countries, ID fellowship programs remain unfilled every year. In 2019, 75 out of 401 positions in ID (19\%) were unfilled in the USA and only 3 medical specialties among the 68 specialties evaluated had a higher number of unfilled positions (geriatric medicine, nephrology and ultrasound medicine) [7]. Canada has also described difficulties in finding ID residents and fellows [8, 9]. Moreover, ID is still not widely recognized as a qualifying specialty in many countries including Spain or India $[10,11]$. Studies in the USA have identified dissuading factors from choosing the ID specialty and potential targets for action, such as a low salary or an unsatisfying work-life balance. However, we do not know if these factors are similar across countries [12, 13].

In 2017, France undertook a reform of residency that created new qualifying specialties such as infectious and tropical diseases. From 2017 onward, a fixed number of positions in ID are opened every year in each city of France. At the end of medical school, French students take a national ranking exam and the medical and surgical specialties are chosen according to their rank: from the first ranked to the last, each medical student chooses a city and a specialty. Before this reform, ID was a subspecialty that could only be chosen after completing another residency (usually internal medicine or family medicine).

The creation of the ID residency represents an interesting opportunity to know how and why the specialty is chosen by French medical students and to explore their expectations, motivations and reservations when choosing ID.

\section{Methods}

\section{Choice of ID specialty}

The national ranking, the choice of city and the choice of specialty of each medical student are published every year in the French ministry of Health official journal [14]. We used the publication of the medical students' choice of specialty in 2017 and 2018 to analyze the median rank in each specialty. We included every medical student entering residency in 2017 and 2018 in France.

\section{Questionnaire development and population}

A web questionnaire to explore the factors influencing the choice of ID residency was developed using SurveyMonkey by a working group of 15 ID specialists. The working group included one professor, two hospital practitioners, six fellows and six residents. The questionnaire took into account previous questionnaires on the topic [12, 13] and was adapted for the French curriculum. The questionnaire was reviewed and tested by two first-year ID residents to check for simplicity and comprehensiveness and was modified according to comments. The survey was anonymous and received approval from the French data protection authority (CNIL, registration number: 2213137).

The questionnaire was split into three parts (supplementary material). The first part collected information about demographics, medical school curriculum, expectations from ID residency and career plan. The second part focused on the motivations and reservations of ID residents when choosing the specialty. To explore this, we chose 36 factors relative to ID (Fig. 2) and asked the participants to use a slider to decide if it discouraged them or encouraged them to choose ID. The following legend was shown at the top of the slider for each factor: "strongly discouraged me to choose ID" at the far left, "did not influence my choice" in the middle and "strongly encouraged me to choose ID" at the far right. The slider position was then linked to a number between 0 ("strongly discouraged me to choose ID") and 10 ("strongly encouraged me to choose ID") to do the statistics and box plots. To capture other factors that could have been missed, we asked the participants if they thought of other factors that influenced their choice. The third part collected information about likely measures to increase the attractiveness of ID. We asked the participants to decide if a selection of 12 measures were very unlikely, unlikely, neutral, likely or very likely to increase the attractiveness of the specialty. We selected the 12 measures based on the literature $[12,13]$ and on the modifiable factors that were evaluated in the second part of the questionnaire. The 36 factors and 12 measures were displayed in a random order for each participant to avoid biases due to changes in the participant's way of rating during the questionnaire (e.g. modification of the concentration level).

The questionnaire was sent on 29th January 2019 by email to all the residents who had chosen ID since the creation of the specialty in $2017(n=100)$ via the Young French Infectious Diseases Physicians' Network (RéJIF), a working group of the French Society for Infectious 
Table 1 Choice of medical and surgical specialties after medical school in France

\begin{tabular}{|c|c|c|c|c|c|c|c|c|c|c|c|c|}
\hline \multirow[t]{2}{*}{ Ranking } & \multirow[t]{2}{*}{ Specialty } & \multirow{2}{*}{$\begin{array}{l}\text { Mean } \\
\text { median } \\
\text { rank }\end{array}$} & \multicolumn{5}{|l|}{2017} & \multicolumn{5}{|l|}{2018} \\
\hline & & & $\begin{array}{l}\text { Median rank } \\
\text { [IQR] }\end{array}$ & First & Last & Opened & Unfilled & $\begin{array}{l}\text { Median rank } \\
\text { [IQR] }\end{array}$ & First & Last & Opened & Unfilled \\
\hline 1 & $\begin{array}{l}\text { Infectious and } \\
\text { tropical diseases }\end{array}$ & 526.5 & 402 [179-1146] & 1 & 3709 & 49 & 0 & 651 [154-1690] & 1 & 3209 & 51 & 0 \\
\hline 2 & Ophtalmology & 603.75 & 578 [294-1028] & 3 & 2158 & 129 & 0 & 629 [275-1027] & 18 & 1830 & 150 & 0 \\
\hline 3 & $\begin{array}{l}\text { Plastic, reconstructive } \\
\text { and aesthetic surgery }\end{array}$ & 723 & 675 [411-929] & 29 & 1553 & 27 & 0 & 771 [440-1390] & 80 & 2177 & 29 & 0 \\
\hline 4 & Nephrology & 734.25 & 748 [297-1622] & 15 & 4395 & 76 & 0 & 720 [258-2087] & 10 & 3791 & 80 & 0 \\
\hline 5 & $\begin{array}{l}\text { Cardiovascular } \\
\text { medicine }\end{array}$ & 839.75 & 795 [364-1532] & 4 & 2887 & 170 & 0 & 884 [407-1637] & 23 & 2678 & 181 & 0 \\
\hline 6 & $\begin{array}{l}\text { Dermatology- } \\
\text { Venereology }\end{array}$ & 1096 & 1091 [487-1556] & 33 & 2247 & 90 & 0 & 1101 [482-1459] & 11 & 2448 & 95 & 0 \\
\hline 7 & $\begin{array}{l}\text { Radiology and } \\
\text { medical imaging }\end{array}$ & 1229 & 1192 [690-1818] & 8 & 2536 & 245 & 0 & 1266 [667-1923] & 3 & 3076 & 254 & 0 \\
\hline 8 & Hematology & 1444 & 1461 [483-4228] & 22 & 5628 & 44 & 0 & 1427 [539-3546] & 86 & 5790 & 44 & 0 \\
\hline 9 & Oncology & 1499.5 & 1479 [870-2461] & 39 & 4146 & 117 & 0 & 1520 [736-2526] & 12 & 3935 & 120 & 0 \\
\hline 10 & $\begin{array}{l}\text { Otorhinolaryngology - } \\
\text { Craniofacial surgery }\end{array}$ & 1501 & 1339 [929-2055] & 174 & 3147 & 76 & 0 & 1663 [999-2344] & 56 & 3254 & 81 & 0 \\
\hline 11 & Neurology & 1645 & 1374 [636-2322] & 16 & 3643 & 121 & 0 & 1916 [723-2981] & 5 & 4280 & 127 & 0 \\
\hline 12 & Neurosurgery & 1670.5 & 1204 [538-2246] & 190 & 3986 & 21 & 0 & 2137 [1039-3724] & 228 & 5595 & 25 & 0 \\
\hline 13 & Maxillofacial surgery & 1780.75 & 2002 [946-2445] & 140 & 2870 & 24 & 0 & 1559 [1133-2043] & 311 & 3250 & 27 & 0 \\
\hline 14 & $\begin{array}{l}\text { Intensive care } \\
\text { medicine }\end{array}$ & 1811.75 & 1366 [615-2648] & 107 & 4271 & 64 & 0 & 2257 [832-4177] & 49 & 5318 & 72 & 0 \\
\hline 15 & $\begin{array}{l}\text { Hepato- } \\
\text { Gastroenterology }\end{array}$ & 1883.75 & 1720 [771-2697] & 71 & 3971 & 122 & 0 & 2047 [937-2779] & 6 & 4332 & 128 & 0 \\
\hline 16 & $\begin{array}{l}\text { Internal medicine and } \\
\text { clinical immunology }\end{array}$ & 1898.5 & 1831 [477-4135] & 2 & 5693 & 113 & 0 & 1966 [652-4059] & 7 & 6801 & 123 & 0 \\
\hline 17 & $\begin{array}{l}\text { Orthopedic and } \\
\text { trauma surgery }\end{array}$ & 1913.5 & 1977 [1366-2783] & 170 & 3467 & 116 & 0 & 1850 [1157-2712] & 2 & 3887 & 121 & 0 \\
\hline 18 & Urology & 1997.25 & 2075 [1124-3129] & 224 & 3888 & 61 & 0 & 1919 [906-2966] & 44 & 4088 & 62 & 0 \\
\hline 19 & Rheumatology & 2081.5 & 1916 [1298-2730] & 63 & 4290 & 83 & 0 & 2247 [1524-3171] & 94 & 4159 & 86 & 0 \\
\hline 20 & $\begin{array}{l}\text { Anaesthesiology and } \\
\text { intensive care }\end{array}$ & 2103.5 & 2165 [1162-2972] & 24 & 4083 & 445 & 0 & 2042 [1081-2963] & 25 & 4079 & 465 & 0 \\
\hline 21 & Nuclear medicine & 2311 & 2080 [1635-2746] & 314 & 3122 & 31 & 0 & 2542 [1808-3181] & 268 & 3797 & 33 & 0 \\
\hline 22 & Pulmonology & 2614 & 2346 [1400-3531] & 129 & 4624 & 116 & 0 & 2882 [2011-3788] & 8 & 4557 & 121 & 0 \\
\hline 23 & $\begin{array}{l}\text { Obstetrics and } \\
\text { gynecology }\end{array}$ & 2757 & 2614 [1849-3474] & 204 & 4538 & 197 & 0 & 2900 [2039-3747] & 61 & 4843 & 204 & 0 \\
\hline 24 & Oral surgery & 2808.5 & 2613 [1986-3013] & 1520 & 3191 & 12 & 0 & 3003 [2115-3258] & 1989 & 4127 & 12 & 0 \\
\hline 25 & Pediatrics & 3150.25 & 2950 [1776-3915] & 83 & 5129 & 316 & 0 & 3350 [1897-4401] & 96 & 6141 & 330 & 0 \\
\hline 26 & Gynecology & 3157.25 & 2985 [2271-3658] & 564 & 4600 & 64 & 0 & 3329 [2390-4279] & 347 & 5331 & 81 & 0 \\
\hline 27 & Pediatric surgery & 3184.75 & 3157 [2574-3606] & 701 & 4103 & 24 & 0 & 3212 [1926-3863] & 918 & 5169 & 22 & 0 \\
\hline 28 & Pathology & 3330 & 2611 [1212-3350] & 31 & 4199 & 56 & 0 & 4049 [2461-4970] & 582 & 5611 & 60 & 0 \\
\hline 29 & $\begin{array}{l}\text { Gastro-enterologic } \\
\text { surgery }\end{array}$ & 3398.5 & 3265 [2423-3755] & 121 & 4509 & 77 & 0 & 3532 [2462-4368] & 441 & 5247 & 80 & 0 \\
\hline 30 & Vascular medicine & 3678.75 & 3657 [3116-4115] & 735 & 4635 & 44 & 0 & 3700 [3122-4134] & 559 & 4633 & 46 & 0 \\
\hline 31 & $\begin{array}{l}\text { Thoracic and } \\
\text { cardiovascular surgery }\end{array}$ & 3761 & 3804 [2761-4148] & 807 & 4510 & 25 & 0 & 3718 [2482-5094] & 217 & 5624 & 24 & 0 \\
\hline 32 & Vascular surgery & 3765 & 3615 [2740-3942] & 640 & 4439 & 29 & 0 & 3915 [3172-4167] & 1980 & 4505 & 28 & 0 \\
\hline 33 & $\begin{array}{l}\text { Endocrinology. } \\
\text { diabetes and nutrition }\end{array}$ & 4120.5 & 4061 [2068-4685] & 166 & 5752 & 80 & 0 & 4180 [3128-5380] & 375 & 6667 & 82 & 0 \\
\hline
\end{tabular}


Table 1 Choice of medical and surgical specialties after medical school in France (Continued)

\begin{tabular}{|c|c|c|c|c|c|c|c|c|c|c|c|c|}
\hline \multirow[t]{2}{*}{ Ranking } & \multirow[t]{2}{*}{ Specialty } & \multirow{2}{*}{$\begin{array}{l}\text { Mean } \\
\text { median } \\
\text { rank }\end{array}$} & \multicolumn{5}{|l|}{2017} & \multicolumn{5}{|l|}{2018} \\
\hline & & & $\begin{array}{l}\text { Median rank } \\
\text { [IQR] }\end{array}$ & First & Last & Opened & Unfilled & $\begin{array}{l}\text { Median rank } \\
\text { [IQR] }\end{array}$ & First & Last & Opened & Unfilled \\
\hline 34 & $\begin{array}{l}\text { Physical medicine } \\
\text { and rehabilitation }\end{array}$ & 4236.75 & 4128 [2695-4968] & 569 & 5926 & 94 & 0 & 4345 [3267-5068] & 73 & 7068 & 99 & 0 \\
\hline 35 & Allergology & 4736.5 & 4478 [3614-5277] & 2055 & 6399 & 27 & 0 & 4995 [3949-5602] & 2367 & 6682 & 28 & 0 \\
\hline 36 & Medical genetics & 5354.75 & 3717 [2120-4737] & 582 & 5801 & 20 & 0 & 6992 [3750-7690] & 57 & 8470 & 20 & 0 \\
\hline 37 & Emergency medicine & 5662.75 & 5454 [4374-6677] & 331 & 8285 & 460 & 0 & 5871 [4631-7120] & 1103 & 8693 & 469 & 21 \\
\hline 38 & $\begin{array}{l}\text { Legal medicine and } \\
\text { medical jurisprudence }\end{array}$ & 5795.75 & 5768 [4936-6665] & 1187 & 7441 & 26 & 0 & 5823 [4976-6368] & 1500 & 7618 & 27 & 0 \\
\hline 39 & General medicine & 5846 & 5812 [4346-6969] & 50 & 8372 & 3132 & 187 & 5880 [4401-7140] & 62 & 8706 & 3268 & 163 \\
\hline 40 & Psychiatry & 6024.5 & 5773 [4250-7217] & 84 & 8344 & 494 & 8 & 6276 [4504-7584] & 495 & 8685 & 528 & 18 \\
\hline 41 & Geriatrics & 6128 & 6164 [4714-7550] & 275 & 8371 & 200 & 29 & 6092 [3984-7345] & 72 & 8684 & 199 & 36 \\
\hline 42 & Public Health & 6681.5 & 6256 [4055-7589] & 390 & 8211 & 84 & 5 & 7107 [6325-8179] & 1063 & 8674 & 90 & 21 \\
\hline 43 & Clinical biology & 6860.25 & 6212 [5081-7556] & 244 & 8363 & 110 & 0 & 7508 [6356-8065] & 1366 & 8695 & 111 & 20 \\
\hline 44 & $\begin{array}{l}\text { Occupational } \\
\text { medicine }\end{array}$ & 7698.5 & 7572 [6264-8037] & 1012 & 8370 & 137 & 48 & 7825 [6903-8282] & 3012 & 8699 & 129 & 48 \\
\hline
\end{tabular}

Diseases (SPILF). A reminder was sent on 14th February 2019. No incentive was provided.

\section{Statistical analysis}

Data from the survey were imported into R software (version 3.2.4). Numerical data are presented as absolute numbers, proportion, median \pm interquartile range (IQR).

To represent the choice of medical and surgical specialties by the medical students, we drew a ridgeline plot which represents a superposition of density curves by choice of specialty according to the ranking of medical students in 2017 and 2018. We used the R packages "ggridges" and "ggplot2" for the ridgeline plot.

\section{Results}

\section{Choice of ID specialty}

We analyzed the choice of medical or surgical specialty of 17,078 medical students: 8372 who took the French national ranking exam in 2017 and 8706 in 2018 (Table 1). Forty-nine and 51 positions for the ID specialty were respectively opened in 2017 and 2018 and all were filled. ID was the first-chosen specialty among all specialties with a mean median rank of 526/8539 (Fig. 1). Both in 2017 and in 2018, the first nationally ranked medical student chose the ID specialty. ID was not available for medical students ranked over 3709th out of 8372 in 2017 and over 3209th out of 8706 in 2018. ID specialty was followed by ophthalmology (mean median rank 604) and plastic surgery (mean median rank 723).

\section{Survey participants}

The survey was sent by email to all the ID residents in France $(n=100)$. The response rate to the survey was
90\%: 46 women and 44 men, median age of 25 years (IQR, 24-25.25) completed the survey (Table 2). Residents from every residency program of ID in France participated in the survey (supplementary material). The median delay between the beginning of the ID residency and the survey was 9 months (IQR 3-15). Among the residents who participated in the study, two (2\%) dropped out of the ID residency program, one to join the general medicine residency because of the workload in ID and one who finally chose the orthopedic surgery residency after having hesitated between the two specialties for years.

\section{Expectations and career plan}

Seventy-one participants (79\%) did an internship in an ID department during medical school and 27 participants (30\%) had experience working abroad in a hospital or a non-governmental organization (NGO) during medical school (Table 2). Thirty-nine participants (43\%) decided to choose the ID specialty during medical school and 51 participants (57\%) took their decision after the national ranking exam. The participants mainly hesitated between ID and internal medicine and clinical immunology $(n=31,34 \%)$, family medicine $(n=18,20 \%)$, intensive care $(n=18,20 \%)$, nephrology $(n=17,19 \%)$ and hematology $(n=16,18 \%)$.

When asked about where they wanted to work in the future, the participants cited academic hospitals $(n=68$, $76 \%)$, general hospitals $(n=63,71 \%)$, NGOs $(n=34$, $38 \%)$, research institutes $(n=19,21 \%)$, multidisciplinary health clinic $(n=19,21 \%)$, private hospitals $(n=18$, $20 \%)$, governmental organizations $(n=18,20 \%)$, public health institute $(n=8,9 \%)$ and private surgeries $(n=6$, 


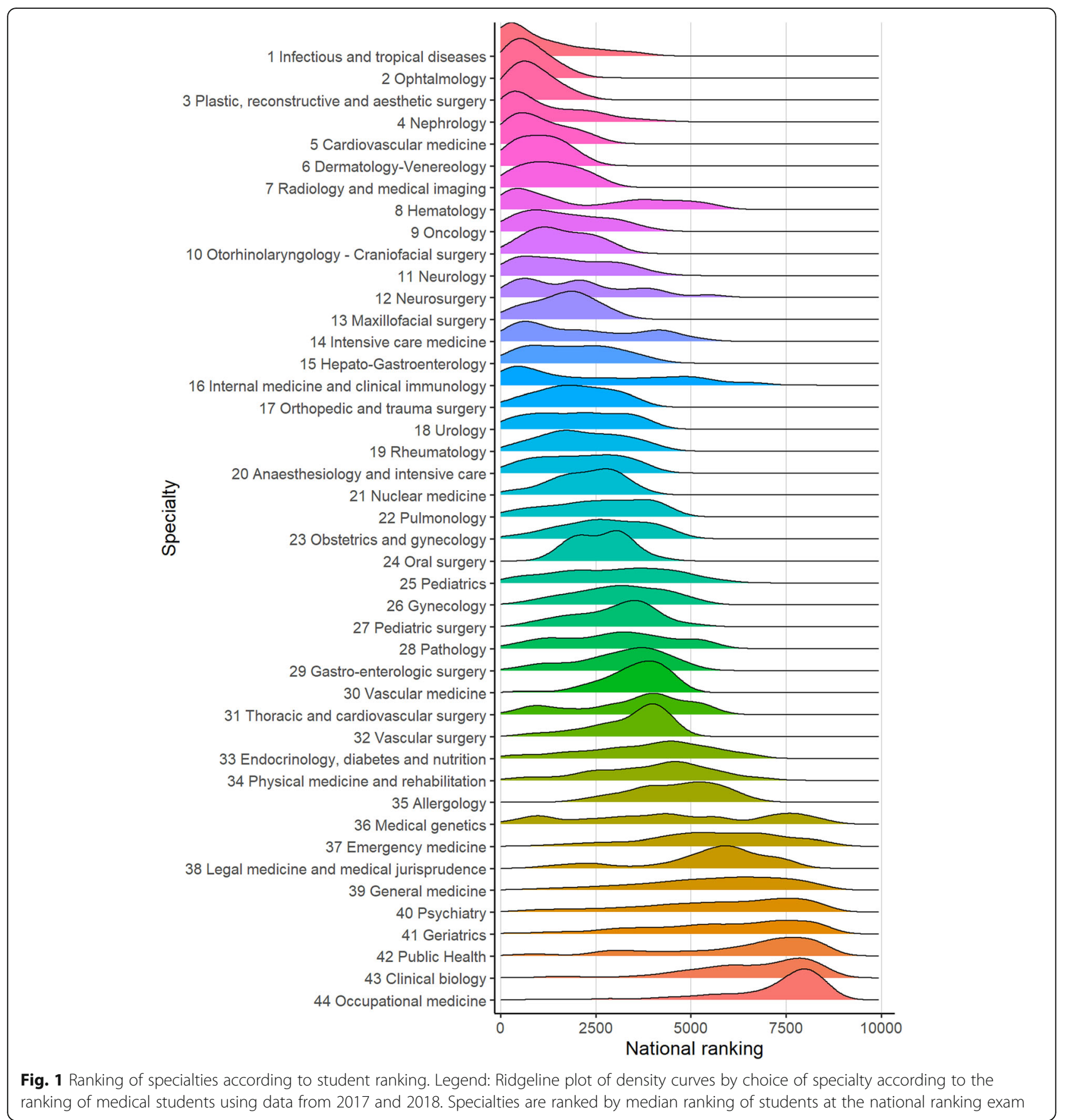

$7 \%)$. Concerning their future position, 87 participants (97\%) declared that they wanted to have a clinical activity, 50 participants $(56 \%)$ a teaching activity and 39 participants $(43 \%)$ a research activity.

Tropical medicine $(n=61,68 \%)$, antimicrobial stewardship $(n=58,64 \%)$, infections of immunocompromised patients $(n=57,63 \%)$ and HIV and sexually transmitted infections $(n=52,58 \%)$ were the areas of ID that interested the most participants. Viral hepatitis $(n=$ $8,9 \%)$, vaccinations $(n=14,16 \%)$ and public health $(n=$
$17,19 \%)$ were the areas of ID that drew the least interest among ID residents.

\section{Motivating factors}

The main motivations to choose ID were (median [IQR]): the multi-system approach of the specialty (10 $[9,10])$, the importance of diagnostic medicine in the specialty (9 [8-10]), having done an internship in ID during medical school $(9$ [7-10]), the fact that ID is a specialty where patients can generally be cured (8 [7- 
Table 2 Demographic characteristics and professional expectations of participants

\begin{tabular}{ll}
\hline & Number $(\%)(\boldsymbol{n}=\mathbf{9 0}$ \\
\hline Women & $46(51)$ \\
Median age (years) $[\mathrm{IQR}]$ & $25[24-25.25]$ \\
Year of national ranking exam & \\
2017 & $48(53)$ \\
2018 & $42(47)$
\end{tabular}

Internship in ID department during medical school

$\begin{array}{ll}\text { Yes } & 71(79) \\ \text { No } & 19(21)\end{array}$

Professional experience abroad before the choice

Yes

$27(30)$

No

$63(70)$

Final decision to choose ID specialty

During medical school
After the national ranking exam
Hesitation with other specialties ${ }^{\mathrm{a}}$
Internal medicine and clinical immunology
Family medicine
Intensive care
Nephrology
Hematology
Hepato-gastro-enterology
Cardiology
Dermatology
Neurology
Oncology

$51(57)$

$31(34)$

$18(20)$

$18(20)$

17 (19)

16 (18)

8 (9)

7 (8)

$6(7)$

$6(7)$

$6(7)$

Interest in the following ID topics

Tropical diseases

$61(68)$

Antimicrobial stewardship

Infections in immunocompromised patients

HIV and sexually-transmitted infections

Emerging infectious diseases

Community-acquired infections

Humanitarian medicine

Travel medicine

Health-acquired infections

Public health

Vaccinations

Viral hepatitis

Most interesting aspects of physicians' work

Diversity of the tasks

Possibility to cure patients

Challenging diagnosis

$46(64)$

Teamwork
Table 2 Demographic characteristics and professional expectations of participants (Continued)

\begin{tabular}{ll}
\hline & Number (\%) ( $\mathbf{n = 9 0 )}$ \\
\hline Patient-physician relationship & $41(57)$ \\
Teaching and mentoring & $39(54)$ \\
Scientific and research work & $31(43)$ \\
Helping vulnerable patients & $30(42)$ \\
Follow-up of outpatients & $15(21)$ \\
Prospective future activity & \\
Clinical activity & $87(97)$ \\
Teaching & $50(56)$ \\
Research & $39(43)$ \\
Prospective working structure & \\
University hospital & $68(76)$ \\
General hospital & $63(71)$ \\
Non-governmental organization & $34(38)$ \\
Research institute & $19(21)$ \\
Multidisciplinary health clinic & $19(21)$ \\
Private hospital & $18(20)$ \\
Governmental organization & $18(20)$ \\
Public health institute & $8(9)$ \\
Private surgery & $6(7)$ \\
\hline Only the specialties cited by more than 5 participants are reported
\end{tabular}

10]) and the global reach of ID (8 [7-10]) (Fig. 2). The creation of a qualifying specialty was a motivating factor $(8[6.75-9])$ as well as the quality of the teaching of ID during medical school (8 [7-9]), the dynamism (8 [7-9]) and ambiance $(7$ [5-8]) in the specialty and the mandatory semester abroad that has been included in the French ID residency (6 [5-8.5]). The participants said that the work-life balance (4 [3-5]), the workload $(4.5[4,5])$, the salary $(5[4,5])$, the availability of clinical positions in teaching hospitals $(5[4,5])$, the availability of academic positions $(5[4,5])$ and the quality of life (5 $[4,5])$ were potential deterrents. The participants were given the opportunity to add any other factors that influenced their choice: 2 participants cited the "prestige" of the specialty as a motivating factor.

\section{Measures to increase the attractiveness of ID}

Improving the quality of life of ID physicians was judged very likely or likely to increase the attractiveness of the specialty by $86 \%$ of participants, increasing the salary by $81 \%$, developing the international network by $81 \%$, developing private practice in ID by $78 \%$, decreasing the workload by $75 \%$, increasing the availability of nonacademic hospital positions by $71 \%$ and increasing the availability of academic positions by $71 \%$ (Fig. 3). Overall, the 12 measures evaluated were judged very likely or 


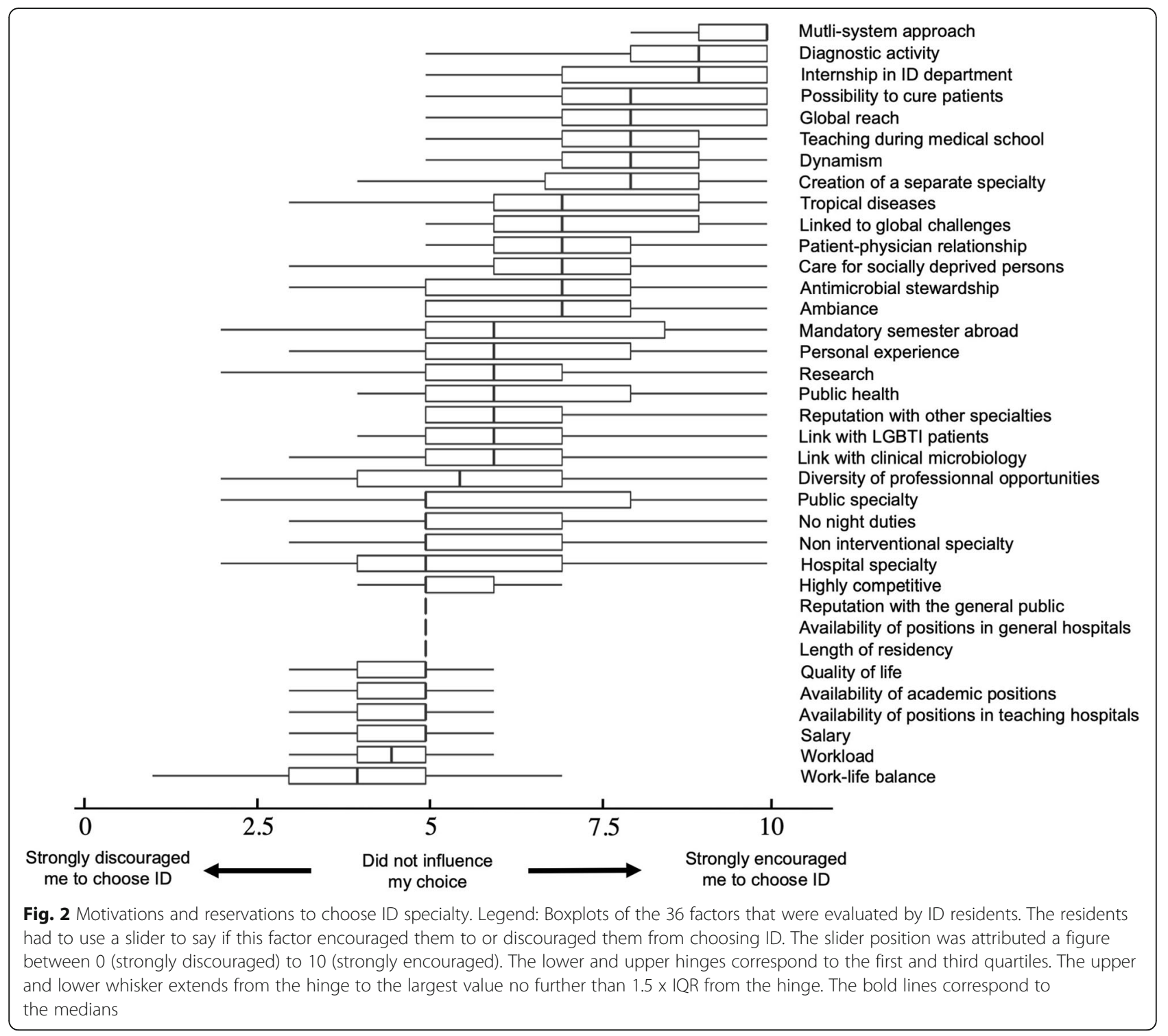

likely to increase the attractiveness of the ID specialty by more than half the participants.

\section{Discussion}

This study brings interesting results for the choice of the ID specialty at a national level. The two most motivating factors to choose ID were the multi-system approach of the specialty and its diagnostic activity. These results indicate that ID should keep its strong internal medicine roots with a diversity of activities instead of moving toward overspecialization. The quality of the teaching of ID as well as an internship in ID during medical school boosted the choice of the specialty. These results are similar to other studies in which ID education and early ID rotation were associated with a career interest in ID $[15,16]$. The international and global reach of ID specialty have been consistently cited as motivating and more than $80 \%$ of the participants thought that the international network should be strengthened. International collaborations are important assets of the specialty and we should increase our effort to build bridges between national and continental societies of ID. The decision to include a mandatory semester abroad in the French ID residency is a step toward this aim and was deemed motivating by most of the participants.

The fact that ID is currently the most popular specialty in France differs from what happens in other countries such as the USA [7]. Yet the deterrents that we identified in our study are really close to the ones identified in previous studies: concern about salary, the work-life balance and limited job availability [12]. While trainees in the USA are probably not more driven by money than in France, the impact of salary on the choice of specialty is probably lower in France than in the USA. 


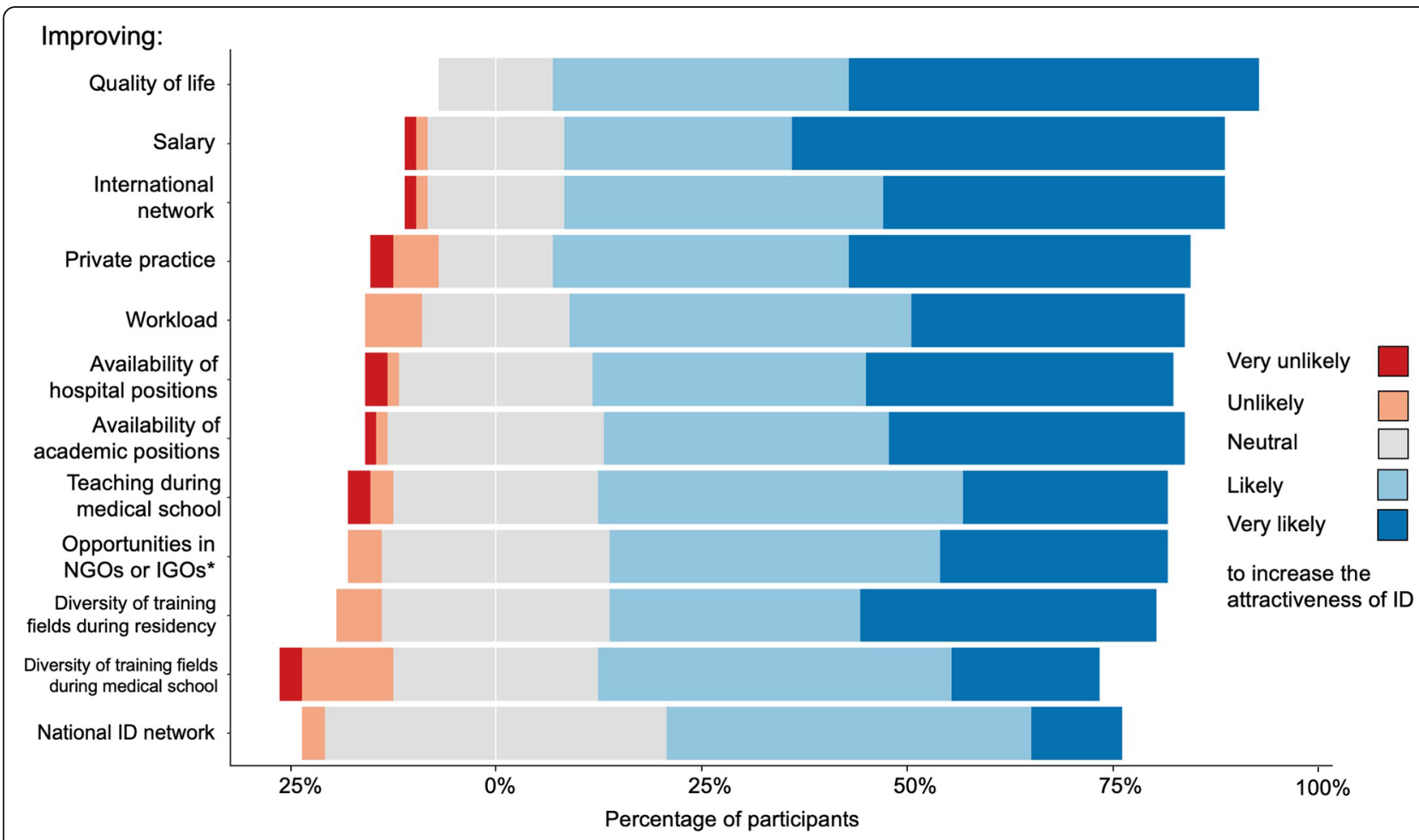

Fig. 3 Could the following measures increase the attractiveness of infectious diseases specialty?. Legend: Likert scale of the 12 potential measures to increase the attractiveness of the specialty evaluated by ID residents. Each bar represents $100 \%$ of the participants and is ranked from most likely to least likely. *: Non-governmental organizations or Intergovernmental organizations (e.g. the United Nations)

Indeed, $>86 \%$ of medical students in the US graduate with debt (approximately \$120,000/student) [17], whereas French medical education is supported by the government and costs around $\$ 500$ per year. As ID physicians are among the lowest paid physicians in the USA [18], student debts may have a higher potential to influence medical students than in France. An increase of the salary of ID physicians in France was still described in our survey as one of the likeliest measures to increase the attractiveness of ID. Recommendations for working toward appropriate compensation for ID physicians have been published and include suggestions such as awarding financial compensation for ID who work in the public service or ensuring that the financial compensation for ID physicians reflects the added value to public health [2]. Studies have reported high rates of burnout symptoms among ID physicians $[19,20]$ and our results confirm that the concerns about the quality of life, the workload and the work-life balance are potential deterrents from choosing ID. The need to improve the worklife balance of physicians is part of the global healthcare system and have to be tackled at the national and political level. To achieve this aim, the ID community probably needs to develop a common advocacy for the ID specialty directed at policy makers and the general public. This research was done before the COVID-19 outbreak but this pandemic further highlights the need to support and encourage students and residents who want to become ID specialists as they are and will be increasingly needed to organize the response to existing and future infectious threats [21].

According to our results, most ID residents want to have a clinical activity (97\%) and a teaching activity (56\%) but less than half want to participate in research (43\%). Scientific research is particularly important in ID with global challenges such as emerging diseases and antimicrobial resistance. The fact that ID physicians in France have an important clinical workload and do not have a dedicated time for research may be an important barrier to the motivation to participate in research [22]. Increasing early research opportunities in ID has been cited as a potential measure toward a reinvigorated interest in the specialty [23, 24]. Tropical medicine and antimicrobial stewardship were the topics that interested the most the participants showing the need for a strong and sustained support for international collaboration and antimicrobial stewardships programs [23], but only $16 \%$ of the participants in our study expressed an interest in vaccination. This finding is worrying, especially with the rise of vaccine hesitancy globally and 
particularly in France [25, 26], however this might be due to the fact that vaccination is a clinical area shared with family medicine and public health.

In this study, we did not contact residents in other specialties and thus cannot analyze the reasons why other students did not choose ID. Moreover, this is a study done in France in a specific healthcare context and only 2 years after the recognition of ID as a qualifying specialty. The network of young ID doctors that is behind this work has been created approximately at the same time as the ID specialty and thus we cannot compare our results with previous data. Our results may not reflect the situation in other countries, especially countries in which medical studies are expensive or countries in which the healthcare system is mainly private. However, this study validates most of the potential measures that have been suggested in previous studies in order to increase the attractiveness of ID, suggesting that our results are not limited to France [12, 13, 23].

\section{Conclusion}

The recognition of ID as a qualifying specialty in France can be considered a success insofar as the specialty reached first rank among all medical and surgical specialties. Individuals who choose ID residency are attracted by the prospect of intellectual stimulation inherent in the specialty (multi-system approach, diagnostic challenges), its global reach and its variety of activities but have reservations regarding the salary, the workload and the availability of positions mainly in university hospitals. According to this national survey, the decision to make ID a qualifying specialty in France strongly encouraged the students to choose ID. These results enable us to be optimistic about the future of this essential specialty and may encourage some countries to recognize ID as a qualifying specialty.

\section{Supplementary Information}

The online version contains supplementary material available at https://doi. org/10.1186/s12909-020-02317-9.

Additional file 1. Supplementary material: map of participating programs.

Additional file 2. Supplementary material: questionnaire.

\section{Abbreviations}

CNIL: French data protection authority; HIV: Human Immunodeficiency Virus; ID: Infectious and tropical Diseases; IQR: Interquartile Range; NGO: NonGovernmental Organization; RéJIF: Young French Infectious Diseases Physicians' Network; SPILF: French Society for Infectious Diseases; USA: United States of America

\section{Acknowledgements}

We thank the RéJIF board:

Simon Bessis, Kévin Bouiller, Mathieu Cabon, Vincent Dubée, Maxime Hentzien, Capucine Martins, Marion Le Maréchal, Julien Gras.
We thank the French National Society for Infectious Diseases (SPILF), the Collège des Universitaires de Maladies Infectieuses (CMIT) and the Association de Chimiothérapie Anti-Infectieuse (ACAI) for their support.

\section{Article's main point}

Since its creation in 2017, infectious and tropical diseases (ID) has been the first-chosen specialty among all specialties in France. We surveyed all ID residents in France to explore the factors influencing their choice of specialty.

\section{Authors' contributions}

Conceived and designed the study and the analysis: NPS, MT. Designed the survey: PT, ALB, GC, LO, VD, AB, AL, MT, NPS. Collected the data: FDA, PT, LO, NPS. Performed the analysis: FDA, NPS. Wrote the manuscript: NPS. Reviewed the manuscript: all authors. All authors have read and approved the manuscript.

\section{Funding}

None.

\section{Availability of data and materials}

The datasets used and/or analysed during the current study are available from the corresponding author on reasonable request.

\section{Ethics approval and consent to participate}

Informed consent was given electronically by all participants. The survey was anonymous and received ethics approval by the French data protection authority (CNIL, registration number: 2213137).

\section{Consent for publication}

Not applicable.

\section{Competing interests}

The authors declare that they have no competing interests.

\section{Author details}

'RéJIF, Young French Infectious Diseases Physicians' Network - Réseau des Jeunes Infectiologues Français, Paris, France. ${ }^{2}$ Infectious Diseases Department, Bichat-Claude Bernard Hospital, Assistance-Publique Hôpitaux de Paris, Paris, France. ${ }^{3}$ Université de Paris, INSERM, IAME, F-75006 Paris, France. ${ }^{4}$ Service de Radiologie II, Hôpitaux Universitaire de Strasbourg, Strasbourg, France. ${ }^{5}$ Service de Maladies Infectieuses et Tropicales, Hôpital Bichat-Claude Bernard, Assistance-Publique Hôpitaux de Paris, Paris, France.

Received: 15 November 2019 Accepted: 20 October 2020

Published online: 31 October 2020

\section{References}

1. World Health Organization. Ten health issues WHO will tackle this year [Internet]. 2019 [cited 2019 Jan 15]. Available from: https:/www.who.int/ emergencies/ten-threats-to-global-health-in-2019.

2. Zahn M, Adalja AA, Auwaerter PG, Edelson PJ, Hansen GR, Hynes NA, et al. Infectious Diseases Physicians: Improving and Protecting the Public's Health: Why Equitable Compensation Is Critical. Clin Infect Dis. [cited 2019 May 9]; Available from: https://academic.oup.com/cid/advance-article/doi/10.1093/ $\mathrm{cid} /$ ciy888/5133590.

3. McQuillen DP, Petrak RM, Wasserman RB, Nahass RG, Scull JA, Martinelli LP. The value of infectious diseases specialists: non-patient care activities. Clin Infect Dis. 2008:47(8):1051-63.

4. Burnham JP, Olsen MA, Stwalley D, Kwon JH, Babcock HM, Kollef MH. Infectious Diseases Consultation Reduces 30-Day and 1-Year All-Cause Mortality for Multidrug-Resistant Organism Infections. Open Forum Infect Dis. 2018;5(3) [cited 2019 May 9]. Available from: https://www.ncbi.nlm.nih. gov/pmc/articles/PMC5852998/.

5. Schmitt S, McQuillen DP, Nahass R, Martinelli L, Rubin M, Schwebke K, et al. Infectious diseases specialty intervention is associated with decreased mortality and lower healthcare costs. Clin Infect Dis. 2014;58(1):22-8.

6. World Health Organization. WHO characterizes COVID-19 as a pandemic [Internet]. 2020 [cited 2020 Mar 14]. Available from: https://www.who.int/ emergencies/diseases/novel-coronavirus-2019/events-as-they-happen.

7. National Resident Matching Program. Results and Data: Specialties matching Service ${ }^{\circledast} 2019$ Appointment Year [lnternet]. Washington, DC: NMRP; 2019. [cited 2019 Jun 22]. Available from: https:// 
mkOnrmpcikgb8jxyd19h.kinstacdn.com/wp-content/uploads/2019/02/ Results-and-Data-SMS-2019.pdf.

8. Horn L, Tzanetos K, Thorpe K, Straus SE. Factors associated with the subspecialty choices of internal medicine residents in Canada. BMC Med Educ. 2008;8:37.

9. Canadian Resident Matching Service. Unfilled positions from the first iteration of the 2019 Medicine Subspecialty Match [Internet]. [cited 2019 May 23]. Available from: https://www.carms.ca/news/unfilled-positions-fromthe-first-iteration-of-the-2019-msm/.

10. Chandrasekar PH. Urgent need for formal medical training in infectious diseases in India. Lancet Infect Dis. 2011;11(11):809-10.

11. McKendrick MW. The European Union of medical specialties core training curriculum in infectious diseases: overview of national systems and distribution of specialists. Clin Microbiol Infect. 2005;11:28-32.

12. Bonura EM, Lee ES, Ramsey K, Armstrong WS. Factors influencing internal medicine resident choice of infectious diseases or other specialties: a National Cross-sectional Study. Clin Infect Dis. 2016;63(2):155-63.

13. Barsoumian AE, Hartzell JD, Bonura EM, Ressner RA, Whitman TJ, Yun HC. Factors influencing selection of infectious diseases training for military internal medicine residents. Clin Infect Dis. 2018;67(10):1582-7.

14. Centre National de Gestion. Assignment of medical students who have passed the national ranking exam leading to the third cycle of medical studies [Internet]. Centre National de Gestion; [cited 2019 May 8]. Available from: https://www.cng.sante.fr/concours-examens/epreuves-classantesnationales-ecn.

15. Blyth DM, Barsoumian AE, Yun HC. Timing of Infectious Disease Clinical Rotation Is Associated With Infectious Disease Fellowship Application. Open Forum Infect Dis. 2018;5(8) [cited 2019 May 9]. Available from: https:// academic.oup.com/ofid/article/5/8/ofy155/5063599.

16. Jeffres MN, Biehle LR, MacDougall C. Comprehensive Assessment of Didactic Curriculum and Career Interest in Infectious Diseases Among Graduating United States Pharmacy Students. Open Forum Infect Dis. 2018;5(11) [cited 2019 May 9]. Available from: https://academic.oup.com/ofid/article/5/11/ ofy284/5151118.

17. American Medical Student Association. Medical student debt. [Internet]. [cited 2019 May 23]. Available from: https://www.amsa.org/advocacy/actioncommittees/twp/medical-student-debt/.

18. Jena $A B$, Olenski $A R$, Blumenthal DM. Sex differences in physician salary in US public medical schools. JAMA Intern Med. 2016;176(9):1294-304

19. Nori P, Bartash R, Cowman K, Dackis M, Pirofski L. Is Burnout Infectious? Understanding Drivers of Burnout and Job Satisfaction Among Academic Infectious Diseases Physicians. Open Forum Infect Dis. 2019;6(4) [cited 2019 May 9]. Available from: https://academic.oup.com/ofid/article/6/4/ ofz092/5364554.

20. Medscape. National Physician Burnout \& Depression Report 2018 [Internet]: Medscape; 2018. [cited 2019 Sep 5]. Available from: https://www.medscape. com/slideshow/2018-lifestyle-burnout-depression-6009235\#1.

21. Peiffer-Smadja N, Lucet J-C, Bendjelloul G, et al. Challenges and issues about organizing a hospital to respond to the COVID-19 outbreak: experience from a French reference centre. Clin Microbiol Infect. 2020;26(6):669-72. https://doi.org/10.1016/j.cmi.2020.04.002.

22. Nair SC, Ibrahim H, Almarzoqi F, Alkhemeiri A, Sreedharan J. Addressing research barriers and facilitators in medical residency. J Fam Med Prim Care. 2019:8(3):1145-50.

23. Walensky RP, del Rio C, Armstrong WS. Charting the future of infectious disease: anticipating and addressing the supply and demand mismatch. Clin Infect Dis. 2017;64(10):1299-301.

24. Chida N, Melia MT, Ghanem KG. Editorial commentary: recruiting the next generation of infectious diseases physicians: how do we reignite the passion? Clin Infect Dis. 2016;63(2):169-71.

25. Larson HJ, de Figueiredo A, Xiahong Z, Schulz WS, Verger P, Johnston IG, et al. The state of vaccine confidence 2016: global insights through a 67country survey. EBioMedicine. 2016;12:295-301.

26. Kernéis $\mathrm{S}$, Jacquet $\mathrm{C}$, Bannay $\mathrm{A}$, May $\mathrm{T}$, Launay $\mathrm{O}$, Verger $\mathrm{P}$, et al. Vaccine education of medical students: a Nationwide cross-sectional survey. Am J Prev Med. 2017:53(3):e97-104.

\section{Publisher's Note}

Springer Nature remains neutral with regard to jurisdictional claims in published maps and institutional affiliations.

\section{Ready to submit your research? Choose BMC and benefit from:}

- fast, convenient online submission

- thorough peer review by experienced researchers in your field

- rapid publication on acceptance

- support for research data, including large and complex data types

- gold Open Access which fosters wider collaboration and increased citations

- maximum visibility for your research: over $100 \mathrm{M}$ website views per year

At $\mathrm{BMC}$, research is always in progress.

Learn more biomedcentral.com/submissions 